\title{
Pemanfaatan Energi Terbarukan Untuk Penerangan Jalan Umum Kampung Padamukti Pangalengan Kabupaten Bandung
}

\author{
Tri Nopiani Damayanti ${ }^{1}$, Irma Safitri ${ }^{2}$, Ratna Gema Maulida ${ }^{3}$ \\ 1Prodi D3 Teknologi Telekomunikasi, Fakultas Ilmu Terapan, Universitas Telkom \\ 2Prodi S1 Teknik Telekomunikasi, Fakultas Teknik Elektro, Universitas Telkom \\ ${ }^{3}$ Prodi D3 Perhotelan, Fakultas Ilmu Terapan, Universitas Telkom \\ e-mail: ${ }^{1}$ damayanti@telkomuniversity.ac.id, 2irmasaf@telkomuniversity.ac.id, \\ 3gema@telkomuniversity.ac.id
}

\begin{abstract}
Abstrak
Intensitas cahaya matahari dapat dimanfaatkan sebagai sumber energi terbarukan. Salah satu pemanfaatannya untuk menunjang infrastruktur dari Penerangan Jalan Umum (PJU) terutama bagi wilayah yang belum terhubung oleh listrik PLN. Kampung Padamukti Pangalengan, letaknya berada di area perkebunan teh dimana akses jalan menuju kampung sampai saat ini tidak memiliki PJU. Hal ini berdampak terhadap kerawanan keamanan sehingga menganggu ketentraman dan kenyamanan warga Kampung Padamukti yang beraktivitas di malam hari. Kegiatan Program Kemitraan Masyarakat (PKM) yang dilaksanakan bertujuan membantu meningkatkan keamanan aktivitas warga Kampung Padamukti yang melintasi akses jalan umum yang belum tersentuh listrik PLN. Metode PKM yang dilakukan melalui pembangunan sistem Penerangan Jalan Umum yang memanfaatkan Tenaga Surya (PJU-TS) dan sosialisasi keilmuan tentang pemanfaatan energi terbarukan berbasis tenaga surya untuk menunjang kegiatan warga. Hasil PKM yang didapatkan adalah meningkatnya pemahaman dan pengetahuan warga Kampung Padamukti tentang pemanfaatan energi terbarukan serta hibah lampu PJU-TS untuk membantu dan meningkatkan keamanan warga beraktivitas di malam hari.
\end{abstract}

Kata Kunci: Energi Terbarukan, Tenaga Surya, Kampung Padamukti

\section{Abstract}

The intensity of sunlight can be utilized as a renewable energy source. One of its uses to support the infrastructure of solar power street lighting system, especially for areas that have not been reach by PLN electricity. Kampung Padamukti Pangalengan, located in the tea plantation area where the road access to the village until now does not have Public Street Lighting. This has an impact on security risks so as to disturb the peace and comfort of the residents of Kampung Padamukti who activities at night. The activities of the Community Partnership Program (PKM), which are carried out aim to help improve the safety of the activities of the residents of Kampung Padamukti who cross public road accesses that, have not been touched by PLN electricity. The Methods of PKM carried out through the application of solar power street lighting system and scientific socialization on the utilization of solar power street lighting system to support the activities of citizens. The result of this PKM is the increasing understanding and knowledge of the people of Kampung Padamukti about the 
utilization of renewable energy as well as solar power street lighting system grants to help and improve the safety of residents' activities at night

Keywords: Renewable Energy, Solar Energy, Padamukti Village

\section{Pendahuluan}

Pada daerah Kabupaten Bandung Jawa Barat terdapat sebuah Kampung Padamukti yang merupakan salah satu bagian wilayah dari Desa Margamukti yang terletak pada ketinggian 1.484,99 mdpl di atas permukaan laut. Berdasarkan data dari, potensi lahan yang dimiliki seluas 2.613,049 $\mathrm{Ha}$, dimana 536,41 Ha adalah tanah perkebunan, perkebunan yang paling besar adalah kebon teh (Margamukti, 2019). Kampung Padamukti yang terletak di Desa Margamukti memiliki potensi alam yang luar biasa berupa sumber geothermal dan panorama alamnya yang sangat indah. Kedua potensi ini sangat menjanjikan harapan sebagai salah satu unsur potensi wisata yang dapat menunjang peningkatan ekonomi Desa Margamukti. Tetapi dibalik potensi alamnya yang luar biasa, Kampung Padamukti memiliki permasalahan dalam hal infrastruktur Penerangan Jalan Umum (PJU). Kampung Padamukti selama ini telah dialiri oleh listrik PLN akan tetapi karena kampung berada di area perkebunan teh dimana akses jalan utamanya menuju Kampung tidak memiliki lampu penerangan jalan (PJU) yang ditunjukkan pada Gambar 1.

Minimnya lampu penerangan jalan umum di Kampung Padamukti menyebabkan kerawanan keamanan pada area perkebunan teh. Sering kali terjadi pembegalan terhadap warga yang melintasi akses jalan tersebut saat beraktivitas dimalam hari. Selain kejahatan, daerah tersebut juga rawan terjadi kecelakaan kendaraan akibat minimnya penerangan jalan dimalam hari terutama saat musim hujan. Permintaan PJU untuk penerangan jalan Kampung Padamukti sebenarnya telah cukup lama di ajukan ke pihak pemerintah terkait oleh perangkat Desa Margamukti, tetapi pengajuan tersebut sampai saat ini belum ada keberlanjutannya. Sedangkan untuk membangun PJU secara mandiri dari warga Kampung Padamukti sangat memberatkan karena mengingat sebagian besar mata pencaharian warganya hanya sebagai buruh tani atau ternak.
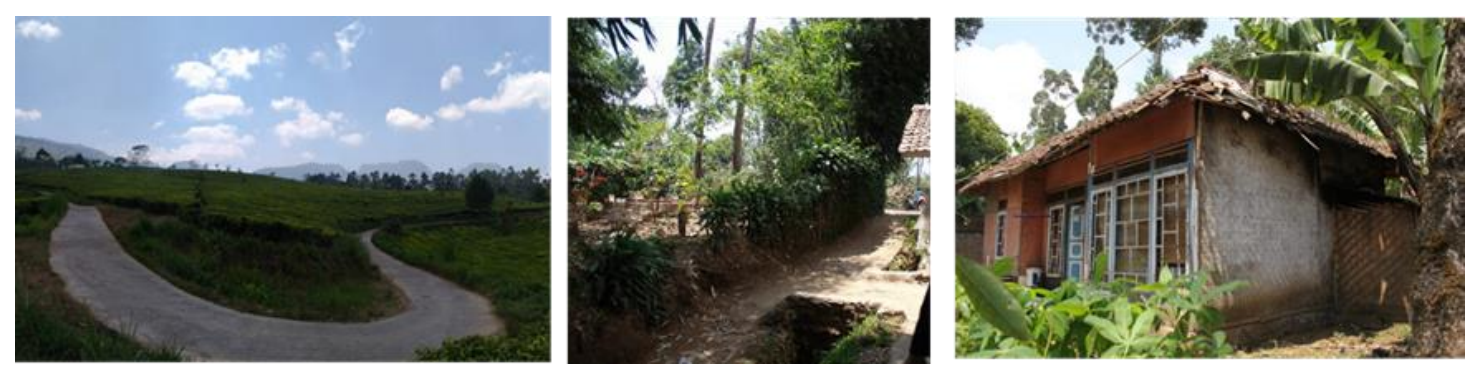

Gambar 1. Kondisi Kampung Pada Mukti

Selama ini warga Kampung Padamukti hanya mengenal sumber listrik yang dapat digunakan hanya bersumber dari listrik PLN yang berbahan dasar minyak dan gas bumi. Kebutuhan konsumsi energi listrik semakin lama semakin meningkat tiap 
tahunnya, di Indonesia tiap tahun kebutuhan energi listriknya diproyeksikan meningkat 6,86 \% (Kementerian Energi dan Sumber Daya Mineral, 2018). Kenaikan ini akan berimbas pada kenaikan kebutuhan bahan bakar dari minyak maupun gas bumi yang ketersediannya semakin kian menyusut tiap tahunnya. Hal ini menjadi tantangan untuk segera melakukan diversifikasi energi pada setiap sektor bidang yang membutuhkan konsumsi energi listrik. Diversifikasi energi yang dapat digunakan untuk keperluan PJU salah satunya dapat memanfaatkan energi dari radiasi matahari yang lebih ramah terhadap lingkungan dan hemat biaya. Energi terbarukan dalam hal ini pemanfaatan energi radiasi matahari mulai banyak dimanfaatkan untuk menunjang kehidupan manusia sehari-hari. Penelitian tentang pemanfaatan fenomena alam seperti radiasi matahari sebagai sumber energi terbarukan untuk PJU telah mulai banyak di lakukan. Penggunaan panel surya untuk sistem penerangan jalan umum mampu mengurangi emisi di lingkungan dan mengurangi biaya operasional dan pemeliharaan (Liu, 2014). Penggunaan panel surya untuk PJU semakin berkembang terutama dengan pemakaian MPTT pada panel surya yang semakin meningkatkan efisiensi dan daya output (Mohammed, 2016).

Negara Indonesia merupakan negara tropis yang memiliki distribusi penyinaran matahari cukup besar di setiap kawasan wilayahnya. Besarnya potensi penyinaran matahari menurut data dari kementerian ESDM pada kawasan barat Indonesia sebesar $4.5 \mathrm{kWh} / \mathrm{m}^{2} /$ hari dengan variasi bulanan sekitar $10 \%$ sedangkan untuk kawasan timur Indonesia sebesar $5.1 \mathrm{kWh} / \mathrm{m} 2 /$ hari dengan variasi bulanan sebesar $9 \%$. Potensi penyinaran matahari ini dapat dimanfaatkan sebagai energi surya melalui penerapan energi terbarukan menggunakan teknologi panel surya. Wilayah Kampung Padamukti yang berada di dataran tinggi di Kabupaten Jawa Barat memiliki intensitas radiasi matahari yang cukup tinggi sebesar $2.558(\mathrm{Wh} / \mathrm{m} 2)$ (Raharjo \& Fitriana, 2018). Kondisi intensitas cahaya matahari tersebut memungkinkan diterapkannya Energi surya sebagai sumber energi terbarukan untuk Penerangan Jalan Umum Kampung Padamukti. Berdasarkan survey dengan melihat potensi daerah Kampung Padamukti, permasalahan tidak adanya PJU pada jalan akses utama harus segera diatasi. Permasalahan ini dapat diatasi melalui sebuah kegiatan Program Pengabdian Masyarakat melalui program PKM yang dilaksanakan oleh dosen Universitas Telkom dibantu dengan para mahasiswa serta warga Kampung Padamukti. Kegiatan PKM berupa pemasangan PJU Tenaga Surya (PJU-TS) dilaksanakan oleh Tim PKM Universitas Telkom dan dibantu oleh warga Kampung Padamukti. Pemilihan lampu PJU Tenaga Surya (PJU-TS) didasarkan selain melihat potensi daerah Kampung Padamukti juga dari kajian tentang kemudahan dalam pemeliharaan dengan biaya yang rendah. Hal ini sangat tepat sekali mengingat mayoritas kegiatan ekonomi warga Kampung Padamukti sebagai buruh tani atau buruh ternak yang berpenghasilan rendah.

\section{Metode}

Berdasarkan permasalahan mitra yang telah diuraikan sebelumnya yaitu minimnya lampu PJU di Kampung Padamukti, maka Program Kemitraan Masyarakat memberikan solusi melalui dua metode yang dilaksanakan selama 4 Bulan meliputi: 
a) Sosialisasi tentang PJU Tenaga Surya (PJU-TS)

b) Pemasangan PJU Tenaga Surya (PJU-TS) di dua titik area jalan akses ke Kampung Padamukti yang rawan tindak kejahatan dan kecelakaan.

Pada pelaksanaan PKM, warga Kampung Padamukti sebagai mitra berkontribusi dalam menyediakan area pemasangan PJU-TS serta membantu Tim PKM dalam persiapan, pemasangan dan instalasinya. Sedangkan Tim PKM sebagai tim yang menyediakan perangkat PJU-TS, pemateri dalam sosialisasi pelatihan PJU-TS serta tim utama penggerak pemasangan perangkat PJU-TS.

\section{A. Metode Sosialisasi Tentang PJU Tenaga Surya (PJU-TS)}

Metode pertama yang dilakukan adalah metode pelatihan tentang seputar pengetahuan energi terbarukan khususnya tentang teknologi PJU-TS meliputi prinsip kerja dan teknik pemeliharaan PJU-TS. Berikut merupakan tahapan metode sosialisasi yang dilakukan oleh tim PKM:

\section{Survey melalui Kuisioner}

Sebelum melakukan metode sosialisasi, tim PKM melaksanakan survey berupa wawancara dalam bentuk kuisioner kepada warga Kampung Padamukti serta pejabat RT/RW setempat tentang pengetahuan terkait energi tenaga surya. Survey dilaksanakan sebanyak 4 kali selama 2 minggu. Metode survey dilakukan dalam rangka memudahkan tim PKM mengetahui pemahaman warga terkait PJU-TS serta untuk membuat modul panduan PJU-TS yang tepat dan mudah dipahami warga.

\section{Pembuatan Modul Panduan Operasional PJU-TS}

Setelah survey dilaksanakan maka tim PKM membuat modul panduan terkait PJUTS yang akan dipasang. Modul berisi tentang pengetahuan perangkat PJU-TS, pengoperasiannya serta pemeliharannya.

\section{Sosialisasi PJU-TS}

Kegiatan sosialisasi berupa pelatihan kepada warga Kampung Padamukti dilaksanakan dalam 2 hari kerja. Pelatihan dilaksanakan sebelum pembangunan Instalasi PJU-TS kepada pejabat RT/RW dan warga Kampung Padamukti dengan peserta 20 Orang yang ditunjukkan pada Gambar 2. Pelatihan dilakukan di balai pertemuan RT/RW Kampung Padamukti.
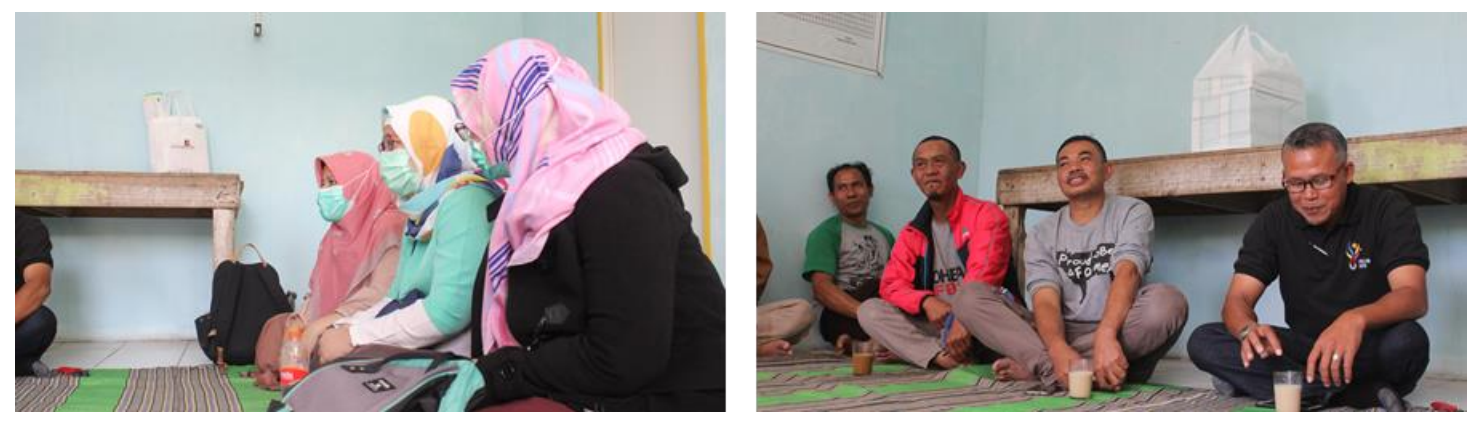

Gambar 2. Sosialisasi PJU Tenaga Surya 
Sebelum sosialisasi dilaksanakan, tim melakukan pre-test untuk mengetahui pemahaman warga sebelum dilaksanakan pelatihan. Pada sosialisasi, pelatihan di bagi menjadi 2 sesi yaitu: sesi pelatihan tentang energi terbarukan, jenis energi terbarukan dan kelebihannya menggunakan energi terbarukan seperti tenaga surya di bandingkan menggunakan energi listrik dari energi fossil. Materi sesi kedua menjelaskan tentang pengetahuan perangkat, prinsip kerja dari PJU-TS dan bagaimana teknik pemeliharaan PJU-TS agar tahan lama. Setelah pelaksanaan pelatihan, Tim melakukan post-test terkait pemahaman warga terhadap materi yang telah diberikan selama sosialisasi berlangsung.

\section{B. Metode Pembangunan PJU Tenaga Surya (PJU-TS)}

Metode kedua yang dilaksanakan adalah melalui pembangunan lampu penerangan jalan atau PJU yang memanfaatkan Tenaga Surya. Pembangunan PJU-TS dilaksanakan tim PKM selama 2 hari kerja dengan dibantu mahasiswa dan warga setempat. Berikut tahapan pembangunan PJU-TS yang dilaksanakan pada program PKM:

\section{Survey titik area penempatan PJU-TS}

Survey dilakukan bersama dengan Pejabat RT/RW Kampung Padamukti, hasilnya didapatkan bahwa PJU-TS ditempatkan di dua area titik akses jalan ke Kampung Padamukti yang rawan tindak kejahatan dan kecelakaan yang ditunjukkan pada Gambar 3. Setelah survey dilakukan, maka dilanjutkan pembuatan lubang pondasi untuk Tiang PJU TS yang ditunjukkan pada Gambar 4.
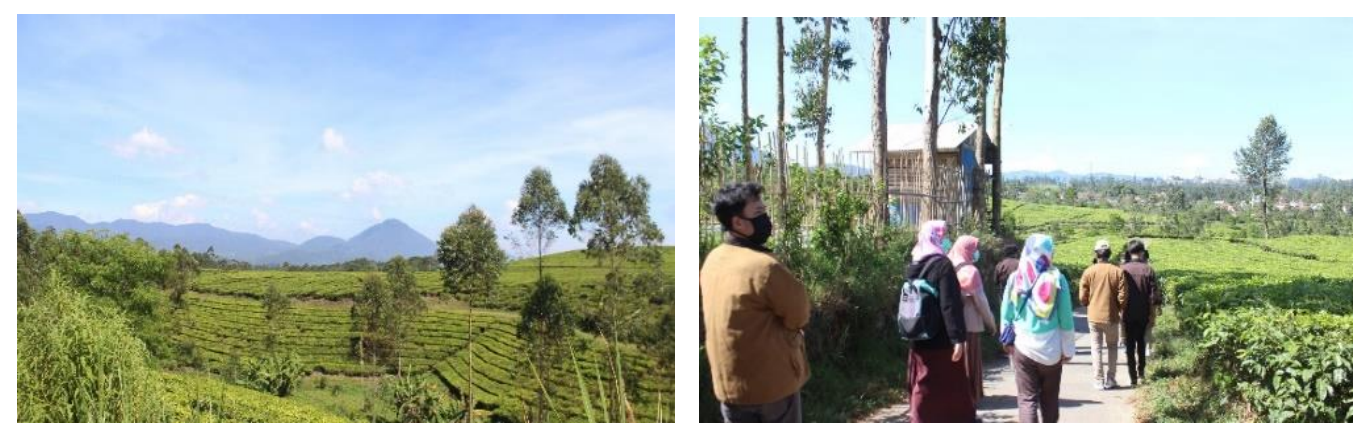

Gambar 3. Survey Titik Area Penempatan PJU-TS
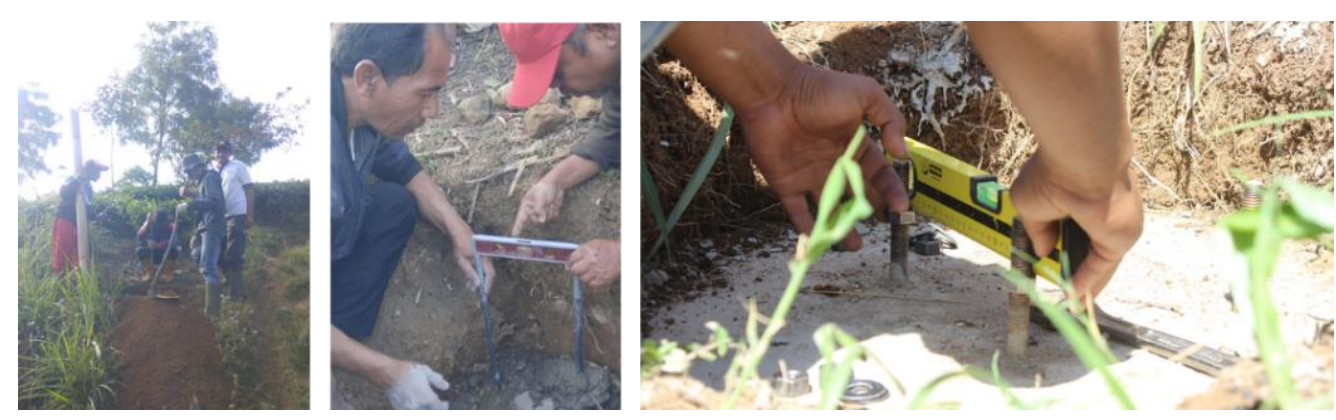

Gambar 4. Pembuatan Lubang Pondasi Tiang PJU-TS 


\section{Penentuan spesifikasi perangkat PJU-TS}

Penentuan spesifikasi perangkat yang dipasang dipilih berdasarkan kajian yang telah dilakukan tim PKM. Penentuan spesifikasi perangkat terutama panel surya harus mempertimbangkan letak geografis area pemasangan PJU-TS. Perangkat PJU - TS terdiri dari panel surya, bracket panel surya battery, solar charger controller, lampu LED dan tiang (Febrianto, Sunanda, \& Gusa, 2019) yang ditunjukkan pada Gambar 5. Pemilihan panel surya perlu mempertimbangkan beberapa kinerja antara lain efisiensi panel surya dimana jika semakin besar efisiensi maka energi listrik yang dihasilkan dari konversinya akan semakin besar. Pemilihan dimensi ukuran panel surya juga harus mempertimbangkan letak geografis wilayah daerah pemasangan PJU.

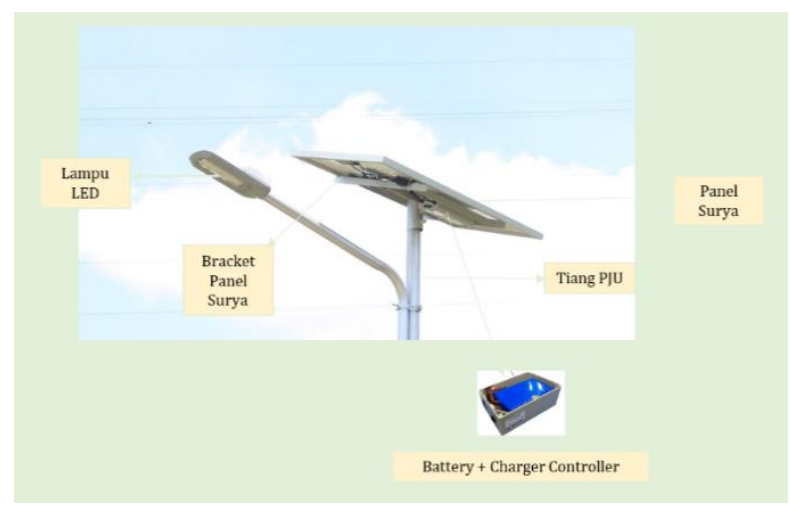

Gambar 5. Perangkat PJU Tenaga Surya

Berikut perhitungan kapasitas panel surya, battery, dod solar charger controller menurut (Anhar et al., 2018). Besarnya kapasitas panel surya harus sesuai dengan beban output yang dapat dinyatakan dalam persamaan 1 :

$$
P_{\text {Panel }}=\frac{E T}{\text { Insolasi Matahari }} \times 1.1
$$

Dimana $\quad: P_{\text {Panel }}$ adalah daya dari panel surya dengan satuannya $\mathrm{Wp}, E T$ adalah energi yang digunakan dengan satuannya Wh dan insolasi matahari menunjukkan besarnya total waktu efektif dalam satu hari penyinaran sinar matahari.

Komponen battery berfungsi sebagai tempat menyimpan cadangan energi dari sinar matahari yang diterima oleh panel surya serta sebagai penyedia daya untuk beban saat matahari tidak dapat menyinari energi ke panel surya. Komponen battery akan menghasilkan energi listrik arus DC pada solar system dengan satuan Ampere hour (Ah). Persamaan 2 menunjukkan besarnya kapasitas dari energi battery yang digunakan:

$$
A h=\frac{E T}{v s}
$$

Dimana Ah adalah daya dari battery dengan satuannya Ah sedangkan vs menunjukkan besarnya tegangan dari battery dengan satuannya Volt. Pada saat perhitungan perlu memperhitungkan besarnya Deep Of Discharge (DOD) sebesar 80\% dengan satuan Ah yang berpengaruh terhadap besarnya kapasitas daya dari batterai $(\mathrm{Cb})$ ditunjukkan pada persamaan 3 berikut ini: 


$$
C b=\frac{A h}{D O D}
$$

Komponen charger controller memiliki fungsi mengatur energi listrik yang berasal dari panel surya menuju battery serta mengatur besarnya energi listrik dari battery ke lampu DC. Penggunaan charger controller pada sistem lampu PJU -TS membuat pengisian energi listrik dari panel surya ke battery dapat diatur sehingga tidak menyebabkan terjadinya overcharging. Besarnya kapasitas arus solar charger controller $\left(I_{\text {maks }}\right)$ dengan satuan Ampere (A) dapat dinyatakan melalui persamaan 4 sebagai berikut:

$$
I_{\text {maks }}=\frac{P_{\text {maks }}}{v s}
$$

Dimana $P_{\text {maks }}$ merupakan besarnya daya kapasitas panel surya yang digunakan dengan satuan Wp dan vs merupakan besarnya tegangan dari panel surya yang digunakan dengan satuan Volt. Perangkat lampu untuk PJU-TS yang digunakan adalah lampu LED karena memiliki life time yang lama dibandingkan lampu biasa. Setelah dilakukan perhitungan dengan mempertimbangkan letak geografis penempatan pju tenaga surya maka didapatkan spesifikasi PJU Tenaga Surya sebagai berikut:

Tabel 1. Spesifikasi Perangkat PJU Tenaga Surya

\begin{tabular}{|l|l|}
\hline \multicolumn{1}{|c|}{ Uraian } & \multicolumn{1}{c|}{ Type } \\
\hline Panel Surya & Modul Surya Polycrystalline 150Wp \\
\hline Battery & $\begin{array}{l}\text { Li-Ion Ncm Rechargeable Battery Pack 11.1volt 60ah, Include Scc 15a Pwm } \\
\text { \& Box }\end{array}$ \\
\hline Lampu LED & $\begin{array}{l}\text { LED-PJU Modular, Maksiman 60W, Seting Dimmer 40 Watt 4jam - 30 Watt } \\
\text { 4 Jam - 20 Watt 4 Jam }\end{array}$ \\
\hline Tiang & $\begin{array}{l}\text { Tiang-Bulat [Blt05bp/Pnt] , 6 Meter, Finishing Cat Chrome, Suport Module } \\
\text { + Baseplate + Angkur + Anti Panjat + Lengan Lampu }\end{array}$ \\
\hline Kabel dan Accesories & $\begin{array}{l}\text { Kabel \& Acc Set-Pju [Pju09001], Kabel Power \& Aksesoris Untuk PJU Single } \\
\text { Arm }\end{array}$ \\
\hline
\end{tabular}

\section{Pemasangan Perangkat PJU-TS}

Pada PKM ini jumlah perangkat PJU-TS yang dipasang sebanyak 2 buah perangkat. Pemasangan perangkat PJU-TS dilakukan oleh tim PKM bersama mitra yaitu warga Kampung Padamukti yang ditunjukkan pada Gambar 6.
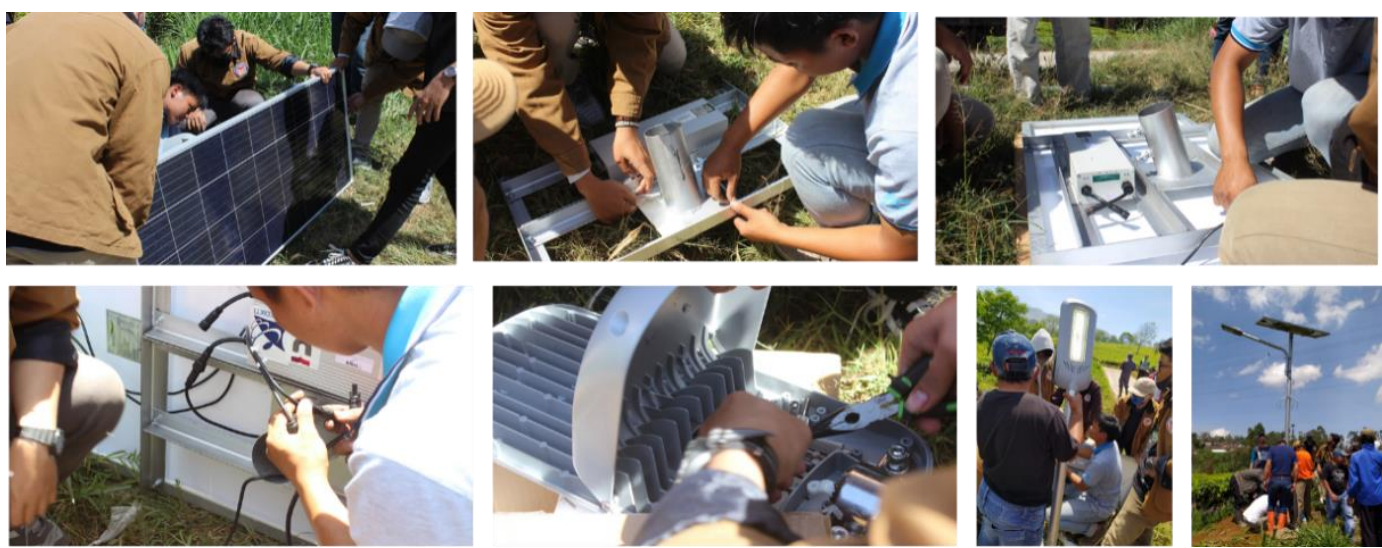

Gambar 6. Proses Pemasangan PJU-TS 
Sebelum pemasangan dilakukan, tim dan warga melakukan pengecekan kondisi keseluruhan dari perangkat panel surya beserta dudukannya, kondisi Baterry Lithium, solar charger controller dengan PWM, lampu LED dan tiang PJU yang akan dipasang. Setelah pengecekan, tim PKM dan warga melakukan perakitan perangkat meliputi pemasangan panel surya pada dudukannya yang dihubungkan ke battery melalui 2 buah konektornya. Battery yang digunakan selain dihubungkan ke panel surya juga dihubungkan ke lampu PJU LED. Langkah berikutnya melakukan pemasangan dan pengetesan solar charger controller dengan PWM sekaligus untuk pengecekan apakah lampu PJU berfungsi dengan baik kemudian langkah berikutnya memasang perangkat sistem PJU-TS ke tiang PJU dan langkah terakhir adalah mendirikan PJUTS di pondasi tiang yang telah dibuat.

\section{Hasil dan Pembahasan}

\section{A. Hasil Sosialisasi Tentang PJU Tenaga Surya (PJU-TS)}

Hasil pelaksanaan sosialisasi pelatihan dievaluasi menggunakan pretest dan post test terhadap mitra yaitu 20 peserta dari warga Kampung Padamukti. Evaluasi bertujuan untuk mengetahui bagaimana pengaruh sosialisasi terhadap wawasan pengetahuan warga tentang PJU-TS.

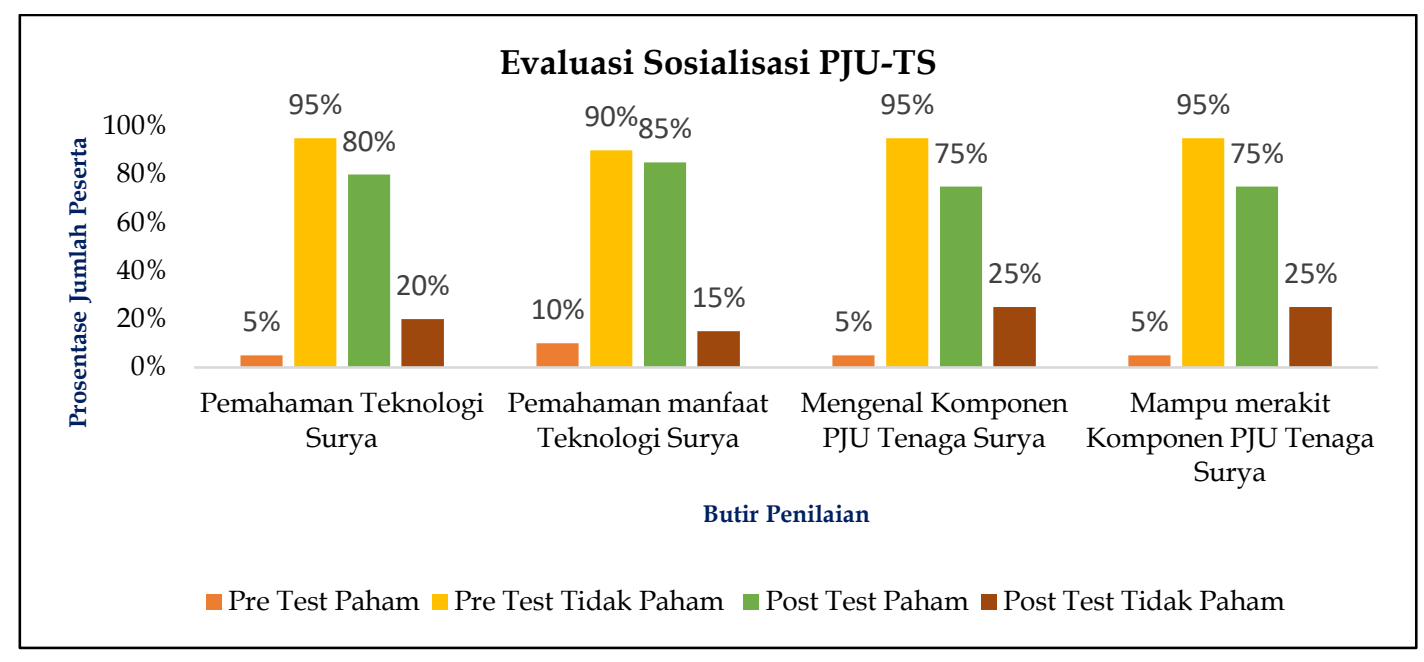

Gambar 7. Grafik evaluasi sosialisasi PJU-TS

Hasil evaluasi pada Gambar 7 menunjukkan bahwa terjadinya peningkatan pemahaman peserta tentang pengetahuan, manfaat, pengenalan tentang teknologi PJU-TS beserta perangkatnya. Selain itu terjadi peningkatan ketrampilan peserta dalam kemampuan merakit perangkat PJU-TS setelah dilakukan sosialisasi.

\section{B. Analisis Pembangunan PJU-TS}

Pembangunan PJU-TS yang memanfaatkan tenaga surya telah dilaksanakan oleh Tim PKM dengan dibantu warga Kampung Padamukti. Keberhasilan dalam pemasangan PJU-TS dapat di lihat saat PJU beroperasi dimana PJU-TS yang dipasang menggunakan kontrol otomatis. Kondisi PJU-TS akan mati saat pagi sampai sore hari dimana pada kondisi tersebut battery melakukan pengisian dan pada malam hari, 
lampu PJU-TS secara otomatis akan menyala yang ditunjukkan pada Gambar 8. Guna mengatur pengisian dan pemutusan arus dari batterai ke lampu maka pada solar charger controller digunakan teknologi Pulse Width Modulation (PWM). Penggunaan teknologi PWM ini, membuat lampu PJU-TS dapat di dimmer sesuai kebutuhan penggunaan beban lampu per jamnya.

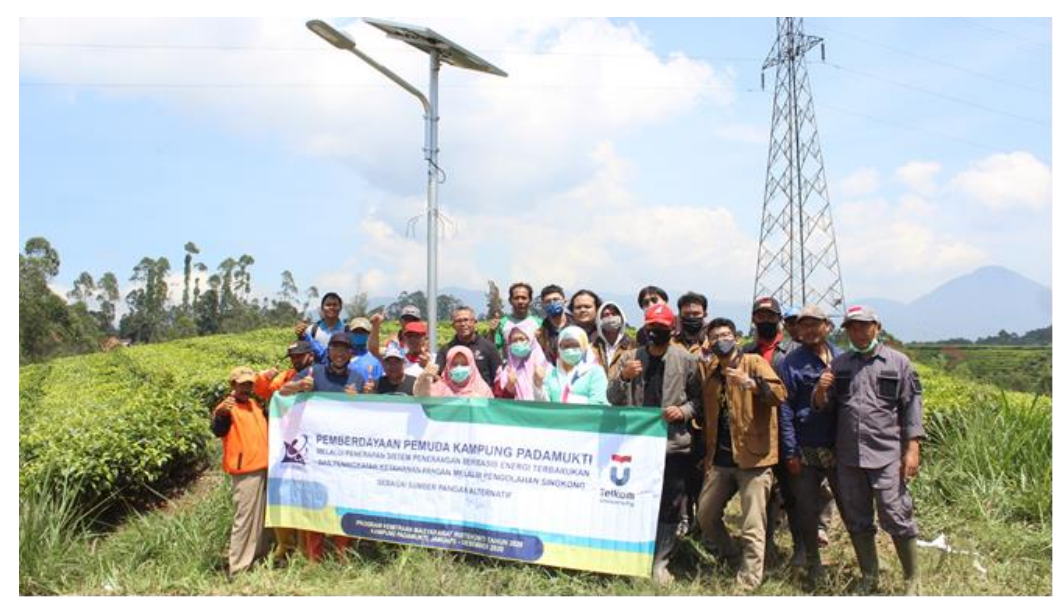

a) Siang Hari

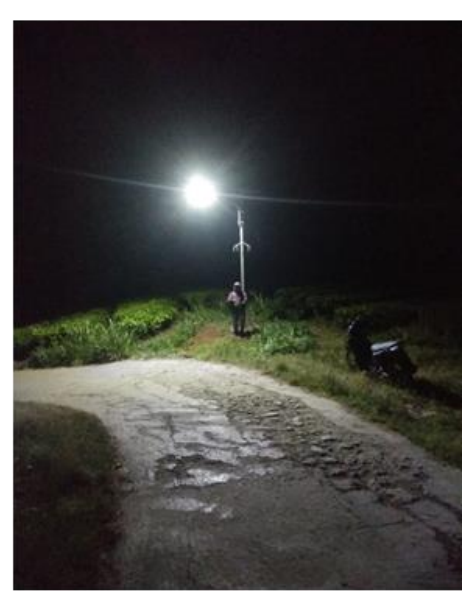

b) Malam Hari

Gambar 8. Kondisi Lampu PJU -TS Terpasang

Guna mengetahui manfaat secara sosial dan lingkungan, tim PKM melakukan evaluasi satu kali secara berkala selama 2 bulan melalui wawancara kepada warga, pejabat RT/RW Kampung Padamukti serta Kepala Desa Margamukti setelah pemasangan PJU-TS. Hasil wawancara menunjukkan meningkatnya keamanan dan keselamatan para warga yang melintasi jalan akses yang telah di pasang PJU-TS terutama yang beraktivitas di malam hari.

\section{Analisis Ekonomi Pembangunan PJU-TS}

Selain manfaat sosial, PJU-TS juga bermanfaat secara ekonomi dan hal tersebut dapat di perhitungkan dengan melakukan perbandingan pembangunan PJU PLN dengan PJU - TS dengan mempertimbangkan besarnya investasi, masa life time perangkat dan pemeliharaan dan biaya beban listrik tiap tahunnya.

\section{1) Biaya Investasi}

Besarnya investasi pembangunan PJU-PLN didapatkan dari data penelitian (Karim, 2016) dimana dalam pembangunannya harus mempertimbangkan beberapa hal seperti pekerjaan persiapan, pekerjaan pemasangan pondasi, pengerjaan pemasangan tiang, pekerjaan pemasangan jaringan kabel, pemasangan panel listrik serta melakukan tes commissioning. Sedangkan besarnya biaya investasi pembangunan PJUTS dihitung berdasarkan harga 1 unit perangkat berikut biaya transportasi material. Besarnya perbandingan biaya investasi pembangunan PJU-PLN dan PJU-TS ditunjukkan pada Tabel 2 berikut ini. 
Tabel 2. Perbandingan Biaya Investasi

\begin{tabular}{|c|c|c|c|c|c|}
\hline \multirow{2}{*}{\multicolumn{2}{|c|}{ Uraian }} & \multicolumn{2}{|c|}{ PJU - PLN } & \multicolumn{2}{|c|}{ PJU-TS } \\
\hline & & \multirow{2}{*}{$\begin{array}{c}\begin{array}{c}\text { Volu } \\
\text { me }\end{array} \\
1 \\
\text { Buah }\end{array}$} & \multirow{2}{*}{$\begin{array}{r}\begin{array}{l}\text { Harga Satuan } \\
(\mathrm{Rp})\end{array} \\
104,309\end{array}$} & \multirow{2}{*}{$\begin{array}{c}\begin{array}{c}\text { Volu } \\
\text { me }\end{array} \\
-\end{array}$} & $\begin{array}{l}\text { Harga Satuan } \\
(\mathrm{Rp})\end{array}$ \\
\hline \multirow{3}{*}{$\begin{array}{c}\text { I. } \\
\text { Pekerjaan } \\
\text { persiapan }\end{array}$} & Papan nama proyek & & & & - \\
\hline & Transportasi material & $1 \mathrm{Ls}$ & 382,424 & 1 & 350,000 \\
\hline & $\begin{array}{l}\text { Pengadaan dan pemasangan } \\
\text { PJU kap stainles pada tiang } \\
\text { besi }\end{array}$ & 1 set & $5,849,100$ & - & - \\
\hline \multirow{12}{*}{\begin{tabular}{l}
\multicolumn{1}{c}{ II. } \\
Pekerjaan \\
pemasang \\
an
\end{tabular}} & Kabel twisted 2x16mm & 1 set & $6,600,000$ & - & - \\
\hline & Kabel NYM 2x2,5 mm & 1 set & 285,000 & - & - \\
\hline & Ajustable dead assy (AL) & 1 set & 704,000 & - & - \\
\hline & $\begin{array}{l}\text { Box panel }(\mathrm{KWH}) \text { kaca } \\
20 \times 40 \times 60 \mathrm{~cm}\end{array}$ & 1 & 475,412 & - & - \\
\hline & Isolasi & 1 & 1,515 & - & - \\
\hline & $\begin{array}{l}\text { Modul Surya Polycrystalline } \\
\text { 150Wp }\end{array}$ & - & - & 1 & $1,500,000$ \\
\hline & $\begin{array}{l}\text { Li-Ion Ncm Rechargeable } \\
\text { Battery Pack 11.1volt 60ah, } \\
\text { Include Scc 15a Pwm \& Box }\end{array}$ & - & - & 1 & $3,800,000$ \\
\hline & $\begin{array}{l}\text { LED-PJU MODULAR, } \\
\text { Maksimal 60W, Seting } \\
\text { Dimmer } 40 \text { Watt untuk 4jam, } \\
30 \text { Watt untuk } 4 \text { Jam, } 20 \text { Watt } \\
\text { untuk } 4 \text { Jam }\end{array}$ & - & & 1 & $1,832,000$ \\
\hline & $\begin{array}{l}\text { Tiang-Bulat [Blt05bp/Pnt] , } 6 \\
\text { Meter, Finishing Cat Chrome } \\
\text { Suport Module + Baseplate + } \\
\text { Angkur + Anti Panjat + } \\
\text { Lengan Lampu }\end{array}$ & - & - & 1 & 618,000 \\
\hline & $\begin{array}{l}\text { Kabel \& Acc Set-Pju } \\
\text { [Pju09001], Kabel Power \& } \\
\text { Aksesoris Untuk PJU Single } \\
\text { Arm }\end{array}$ & - & - & 1 & $1,950,000$ \\
\hline & Pondasi Tiang PJU Beton & - & - & 1 & 500,000 \\
\hline & $\begin{array}{l}\text { Biaya pasang baru daya } 3500 \\
\text { VA }\end{array}$ & $1 \mathrm{Ls}$ & $1,590,909$ & - & - \\
\hline $\begin{array}{l}\text { III. } \\
\text { Jasa/upah }\end{array}$ & Biaya sertifikat laik operasi & $1 \mathrm{Ls}$ & 60,606 & - & - \\
\hline \multicolumn{2}{|r|}{ Investasi PJU 1 unit } & & $16,053,276$ & & $10,550,000$ \\
\hline
\end{tabular}

\section{2) Biaya Operasional Dan Pemeliharaan}

Menurut (Karim, 2016) besarnya biaya yang harus dikeluarkan pertahun untuk PJU yang memanfaatkan energi dari radiasi sinar matahari meliputi pemeliharaan dan operasional sekitar $1 \%$ sampai $2 \%$ yang diperhitungkan dari besarnya dana investasi awal pembangunan. Panel surya yang di gunakan untuk PJU-TS di Kampung Padamukti memiliki life time 25 tahun sedangkan battery memiliki life time 5 tahun sehingga jika perhitungan dilakukan untuk 3 tahun maka selama 3 tahun belum ada perangkat yang diganti. Berdasarkan acuan data tersebut maka didapatkan besarnya 
biaya yang harus dikeluarkan pertahunnya untuk PJU-TS di Kampung Padamukti besarnya sekitar $1 \%$ dari total pembiayaan investasi awal per unit PJU-TS yang ditunjukkan pada perhitungan berikut:

Biaya biaya operasional pemeliharaan PJU-TS:

$=1 \% \times$ Total biaya investasi per unit PJU TS

$=0,01 \times$ Rp.10.550.000,- $=$ Rp. 105.500,-/ tahun per unit.

Sedangkan besarnya biaya operasional PJU-PLN dalam 1 bulan diasumsikan besarnya $1 \%$ investasi yaitu:

$$
=16,054,545 \times 1 \%=\operatorname{Rp} 160,545 \text {,- per Bulan }
$$

Sehingga besarnya biaya operasional PJU PLN adalah : Rp 160,545 x 12 Bulan $=R p$ 1,926,540,- per tahun

\section{3) Biaya Tagihan Beban Listrik Pertahun}

Pada PJU-TS tidak ada beban biaya listrik perbulan dan pertahunnya tapi berbeda untuk PJU - PLN yaitu perhitungan tagihan beban listriknya adalah sebagai berikut : PJU PLN (Asumsi menggunakan Lampu LHE 40 Watt)

Pemakaian Daya Perbulan :

$=$ Daya lampu (watt) $\times$ Total waktu Lampu menyala perhari $\times$ Jumlah hari $=40($ watt $) \times 12(\mathrm{jam}) \times 30$ (hari) $=14.400 \mathrm{Wh}=14,4 \mathrm{kWh}$ per bulan

Biaya tagihan per bulan :

$=$ Pemakaian daya per bulan $\mathrm{x}$ harga $1 \mathrm{kWh}$

$=14,4 \mathrm{kWh} \times \operatorname{Rp} 1.444,7=\operatorname{Rp} 20.804,-$

Besarnya tagihan biaya per titik PJU PLN dalam 1 bulan adalah $=$ Rp 20.804,Sehingga dalam 1 tahun adalah $\mathrm{Rp} 20.804$, 12 bulan = Rp 249.644 / unit PJU PLN

Tabel 3. Perbandingan Ekonomi untuk 1 PJU

\begin{tabular}{|l|r|r|r|r|r|r|}
\hline \multirow{2}{*}{ Biaya } & \multicolumn{3}{|c|}{ PJU TS } & \multicolumn{3}{c|}{ PJU PLN } \\
\cline { 2 - 8 } & $\begin{array}{c}\text { Tahun ke-1 } \\
(\mathrm{Rp})\end{array}$ & $\begin{array}{c}\text { Tahun ke-2 } \\
(\mathrm{Rp})\end{array}$ & $\begin{array}{c}\text { Tahun ke-3 } \\
(\mathrm{Rp})\end{array}$ & $\begin{array}{c}\text { Tahun ke-1 } \\
(\mathrm{Rp})\end{array}$ & $\begin{array}{c}\text { Tahun ke-2 } \\
(\mathrm{Rp})\end{array}$ & $\begin{array}{c}\text { Tahun ke-3 } \\
(\mathrm{Rp})\end{array}$ \\
\hline Investasi & $10,550,000$ & 0 & 0 & $16,054,545$ & 0 & 0 \\
\hline $\begin{array}{l}\text { Operasional } \\
\text { dan } \\
\text { Pemeliharaan }\end{array}$ & 105,500 & 105,500 & 105,500 & $1,926,540$ & $1,926,540$ & $1,926,540$ \\
\hline $\begin{array}{l}\text { Biaya Tagihan } \\
\text { Beban Listrik }\end{array}$ & 0 & 0 & 0 & 249,644 & 249,644 & 249,644 \\
\hline Total & $10,655,500$ & 105,500 & 105,500 & $18,230,729$ & $2,176,184$ & $2,176,184$ \\
\hline
\end{tabular}

Tabel 3 menunjukkan perbandingan biaya secara ekonomi untuk 1 unit PJU yaitu PJU - TS dengan PJU-PLN. Berdasarkan perbandingan diatas terlihat secara ekonomis biaya yang dikeluarkan untuk 1 PJU - TS lebih murah dibandingkan dengan PJU- PLN terutama dari segi biaya beban listrik tiap bulannya PJU-TS tidak ada biaya listrik yang dikeluarkan perbulannya. 


\section{Simpulan dan Rekomendasi}

Kegiatan Program Kemitraan Masyarakat (PKM) Universitas Telkom untuk memecahkan permasalahan mitra di Kampung Padamukti telah berhasil dilaksanakan melalui pembangunan PJU-TS sebanyak 2 titik di akses jalan utama menuju Kampung Padamukti di area perkebunan teh. Pemasangan lampu PJU-TS telah berhasil dioperasikan dan dapat bekerja dengan baik selama 12 jam per hari. Secara ekonomi lampu PJU-TS lebih menguntungkan dibandingkan lampu PJU-PLN karena tidak membutuhkan biaya beban listrik perbulan dan biaya pemeliharaannya pertahun sangat kecil yaitu sebesar Rp.105.500,-

\section{Penghargaan}

Penulis mengucapkan terima kasih kepada Direktorat Riset dan Pengabdian Masyarakat, Deputi Bidang Penguatan Riset dan Pengembangan Kementerian Riset dan Teknologi/Badan Riset dan Inovasi Nasional (RISTEK-BRIN) yang telah memberi dukungan finansial terhadap Program Kemitraan Masyarakat Universitas Telkom untuk tahun anggaran 2020.

\section{Daftar Pustaka}

Anhar, W., Basri, B., Amin, M., Randis, R., \& Sulistyo, T. (2018). Perhitungan Lampu Penerangan Jalan Berbasis Solar System. JST (Jurnal Sains Terapan), 4(1), 33-36. https://doi.org/10.32487/jst.v4i1.449

Febrianto, A., Sunanda, W., \& Gusa, R. F. (2019). Penerangan Jalan Umum Tenaga Surya: Studi Kasus di Kota Pangkalpinang. Jurnal Presipitasi : Media Komunikasi Dan Pengembangan Teknik Lingkungan, 16(2), 76. https:/ / doi.org/10.14710/presipitasi.v16i2.76-82

Karim, S. (2016). Analisa Penggunaan Solar Cell Pada Pju Di Pulau Laut Tengah Kabupaten Kota Baru Kalimantan Selatan. 02(02), 81-91.

Kementerian Energy dan Sumber Daya Mineral. (2018). Executive Summary RUPTL PT PLN 2018-2027. Esdm, 22, 2018-2027. Retrieved from https:/ / www.esdm.go.id/assets/media/content/content-ringkasan-ruptl-20182027.pdf

Liu, G. (2014). Sustainable feasibility of solar photovoltaic powered street lighting systems. International Journal of Electrical Power and Energy Systems, 56, 168-174. https:/ / doi.org/10.1016/j.ijepes.2013.11.004

Margamukti, D. (2019). Profil Desa Margamukti Kecamatan Pengalengan Tahun 2019. 
Mohammed, H. A. Z. (2016). Design and implementation of a photovoltaic system used for street LIGHTS. Proceedings of 2016 2nd International Conference on Control Science and Systems Engineering, ICCSSE 2016, 169-175. https://doi.org/10.1109/CCSSE.2016.7784376

Raharjo, I., \& Fitriana, I. (2018). Analisis Potensi Pembangkit Listrik Tenaga Surya Di Indonesia. 43-52. 